\title{
Perception of the Skills Acquisition Programme of SPDC and NDDC in Rivers and Bayelsa States, Nigeria
}

\author{
URANTA, D \\ Department Of Sociology University Of Port Harcourt, Nigeria
}

\begin{abstract}
This study was carried out to analyze the perception of the Skills Acquisition Programme of Shell Petroleum Development Company (SPDC) and Niger Delta Development Commission (NDDC) in Rivers and Bayelsa States. Twenty-two (22) out of Thirty-five (35) skill centers in both States were purposively selected. Cluster sampling was used to select the skill acquisition centers in the areas and a structured questionnaire was administered to 271 respondents in the study area. The results showed that with a mean score of 3.76, NDDC graduates strongly agreed that the programme cannot bring about rural community development. They disagreed $($ mean $=1.84$ ) that most of the facilities and learning materials are out-of-date. The result also showed that SPDC graduates with a mean score of 2.54, agreed that the programme does assist her graduates in securing jobs while they disagreed $($ mean $=1.77)$ that the programme is more of roadside training and lacks the capacity to train the youths. The mean score of graduates' perception of the programme of NDDC and SPDC respectively were 2.49 and 2.30 . The study thus recommends that the sponsors of the two programmes should ensure that the graduates are promptly absorbed, employed or settled to do something to earn a living.
\end{abstract}

\section{INTRODUCTION}

The efficacy of every organized programme such as the skills acquisition programme is largely dependent on the perception of the target recipients of the programme. Solicited and unsolicited participation of members of the target community for every Skills Acquisition Programme can be garnered when the target group has a positive perception of the programme. Skills acquisition programmes are primarily aimed at reducing the unemployment rate among youths. This is unavoidably pertinent in the Niger Delta region where the continued perpetuation of youth unemployment has resulted in a vast array of adverse effects ranging from Youth restiveness to Niger Delta militancy. In the Niger Delta region, the skill Acquisition programmes were introduced on account of the discovery that the greatest cause unemployment among youths was a lack of learnt (acquired) skills (Nwachukwu and Ekanem, 2016). Nwachukwu and Ekanem (2016) further posited that there is probably no other region of Nigeria that is more plagued with the challenges of unemployment than the Niger delta region. Shell Petroleum Development Company (SPDC) established her Skills Acquisition Programme in 2002 in Old Rivers State, while that of the Niger Delta Development Commission (NDDC) started in 2006 in Rivers State.

Skills Acquisition Training Programme has been rightly defined by Uranta (2016) as an adult education programme which is designed to impart various skills on the participants, and meet immediate needs such as jobs, self-reliance and curb restiveness among youths. It is primarily a training programme that empowers participants to acquire skills in the area of electronics, masonry, carpentry, electricity wiring/installation, hair dressing, barbering, driving, vehicle repair and maintenance, plumbing, fittings, mobile phone repair, computers repair and appreciation among others. It is predominantly a hands-on training modeled to empower the Youths in society with relevant skills and abilities that make them fully adaptable to the prevalent economic situation in Nigeria especially in the Niger Delta region in states like Bayelsa and Rivers State, where population is steadily rising without a commensurate growth in the amount of natural resources, physical resources and industries. Bakare (2013) rightly opined that about 80 per cent of Nigerian youths are unemployed, with secondary school graduates (who are mostly found among unemployed rural population) accounting for about half of this figure. Therefore, innovative programmes such as the Skills Acqusition Training Programmes of SPDC and NDDC will greatly assist in taking a large percentage of these Youths off the streets and help them to become gainfully employed; while also serving as compensation for the environmental degradation caused by the activities of these companies in the target communities.

The Skills Acquisition Programme of the Shell Petroleum Development Company has at the heart of it several objectives which includes to:

1. enable the participants acquire necessary skills for self-employment.

2. enable the youth in the host community be eligible for employment.

3. expose the youth to enterprise management and leadership training. 
4. prepare them for future challenges of self-employment and

5. help the youth acquire vocational skills which will make them self-reliant entrepreneur.

That of the Niger Delta Development Commission has the following objectives to:

1. eradicate poverty in the region (i.e. Niger Delta Region).

2. train youths in vocational skills in various trades such as fishing, welding, automobile and river craft repair etc.

3. produce or create pool of skilled tradesmen.

4. boost the local content of the oil industry and at the same time encourage self-reliance and entrepreneurship among the youth. (Aniete, 2006).

The objectives of the Skills Acquisition Programme of both companies (SPDC and NDDC) introduce an entrepreneurial orientation to the Youths in the States within the Niger Delta region. The entrepreneurial orientation brings about a development of entrepreneurial skills, effective and efficient application of the skills in management of business to create a significant difference from other business, recognizing the skill and allowing it to function effectively (Ogundele, Akingbade, and Akinlabi, 2012). This is a panacea to a myriad of problems such as Poverty, Unemployment etc. that have thus far plagued the Niger Delta region and Nigeria in general.

On the premise of the foregoing, this study seeks to achieve the following objectives as well as test the hypotheses below:

The broad objective of the study was to evaluate the SPDC and NDDC youths skills acquisition programme in rural Niger Delta.

The specific objectives were to:

- identify the socio-economic characteristics of youth in the study area.

- determine the level of participation of the rural youths in skills acquisition training of the Shell Petroleum Development Company and Niger Delta Development Commission in the study areas.

- ascertain the effects of skills acquisition of the programme on the well-being of trained youths of the rural Niger Delta communities.

- evaluate the effectiveness of the Shell Petroleum Development Company and Niger Delta Development programme in their study centres.

- ascertain the perceptions of the graduates beneficiaries and other youths regarding the SPDC and NDDC youths skill acquisition programmes and.

- identify the constraints of the SPDC and NDDC youth skill acquisition programmes.

\section{Study Area}

\section{METHODOLOGY}

The study was carried out in two States (Rivers and Bayelsa States) in the Niger Delta Region which comprises of nine states; namely, Ondo, Edo, Delta, Bayelsa, Rivers, Akwa-Ibom, Cross-River, Abia and Imo state. The region has 188 local government areas and a population of 26.7 million in the year 2002 projection by the Nigerian population commission. It is wetland and covers $70,000 \mathrm{~km}^{2}$. It produces $100 \%$ of Nigeria's oil and gas resources. The region is rich in agricultural resources including palm oil, Cassava, Rubber, Cocoa, cola nut, and a diversity of aquatic resources.

The study was carried out in two States (Rivers and Bayelsa States) in the Niger Delta Region which comprises of nine states; namely, Ondo, Edo, Delta, Bayelsa, Rivers, Akwa-Ibom, Cross-River, Abia and Imo state. The region has 188 local government areas and a population of 26.7 million in the year 2002 projection by the Nigerian population commission. It is a wetland and covers $70,000 \mathrm{~km}^{2}$. It produces $100 \%$ of Nigeria's oil and gas resources. The region is rich in agricultural resources including palm oil, Cassava, Rubber, Cocoa, kola nut, and a diversity of aquatic resources.

The Rivers State was created on $27^{\text {th }}$ May 1967, out of the former Eastern Nigerian. Rivers State is made up various ethnic groups. These groups occupy the Niger Delta.

Rivers people are very hospitable, peaceful, generous and warmhearted; its capital is Port Harcourt. Rivers people are very industrious. Traditionally, they are fishermen, hunter, traders, and carvers. The well-educated ones are into various businesses such as oil sources, the military; River State is surrounded by the following states: Abia, Imo, Akwa Ibom and Bayelsa State. She is one of the oil producing states and coastal states of Nigeria. The state occupies in area of about 30,000, sq kilometers. The State has (23) twenty -three Local Government Areas.

The means of transportation in Rivers State is upland and riverine areas and the State has a seaport and an airport. Riverine areas can be reached by speed-boats, ferries-boats, launches, and canoes. Resources of Rivers State are natural resources can be oil, palm oil, and palm-kernel. Others are agricultural products, Copra, 
fish, citrus, fruits, cassava, plom-caw, bam- are yam weoyam, vegetables etc. The vegetation of the State is mainly mangrove.

Bayelsa is bounded by neighbouring state of River State and Delta States. The state is one of oil and gas exploitation area in Niger Delta region with no serious infrastructural development. Bayelsa state is located in heart of the Niger Delta, and is the center of the crude oil, which sustains the Nigeria Nation- (Alagoa, 1999).

Bayelsa is a State whose population is mostly rural and is majored in fishing, aquaculture, agriculture and hunting. Basically, economic activities in the state which serves as sources of livelihood for the population who are mostly rural include collection of palm produce, handicraft, farming and trading. The Adult men climb the raffia-palm and extract the wine.

The state has many rivers. Transport is affected by dugout canoes and out board engine boats. Others use in boat engine and speedboat.

\section{SAMPLING TECHNIQUE AND SAMPLE SIZE}

The study adopted a Multi-Stage sampling process which consisted of a combination of purposive and random sampling techniques. Multi-stage sampling is a type of sampling that is used when the sampling is to be done in several stages that requires the researcher to employ a varying range of sampling techniques. There is however, no specific order for the implementation of the different sampling techniques. For the purpose of this research, Twenty-two (22) out of thirty-five (35) skill centres were purposively selected in both Bayelsa and Rivers State respectively. A total of 300 respondents were randomly selected and was constituted of a total of one hundred and sixty-six (166) youths in Rivers State and one hundred and five (105) youths in Bayelsa State. These figures indicate a total percentage enrollment of approximately $35 \%$ for Bayelsa State and $65 \%$ for Rivers State. A structured questionnaire was issued to each respondent but a total of two hundred and seventy-one (271) were retrieved for analysis from the twenty-two (22) centres. A total Twenty-nine (29) copies of the questionnaire were discarded due to incomplete information and inconsistency. Thus, 271 respondents constituted the sample size for the study.

\section{METHOD OF DATA COLLECTION AND ANALYSIS}

Data collection was done with the aid of a well-structured Questionnaire, Interview, Focus Group Discussion (FGD), review of relevant Literature, and experienced enumerators and local interpreters were used. Data analysis was subjected to both descriptive and inferential statistics (using SPSS software). Descriptive statistics were mainly frequency count, percentages, mean and appropriate measure of central tendencies, and tables. The following inferential statistics were used according to their models: Associated statistics, Multiple Regression, and Analysis of Variance (ANOVA).

\section{RESULTS AND DISCUSSION}

\section{Respondents' Perception of the Skills Acquisition Programme of SPDC and NDDC in Rivers and Bayelsa} States

In table 4.6 it could be seen that the respondents of both NDDC and SPDC agreed to the first item which held that Youth Development Programme was totally different and better than other oil companies' in their areas. While NDDC trainees agreed that the programme was political in nature, to the extent that only people loyal to and related to the ruling party benefited more from the programme, SPDC participants disagreed to that suggestion. Both NDDC and SPDC trainees disagreed to the following items: "The programme has not yet taken off in my community, we only hear of it and read of it in the Newspaper/Radio"; (3) The implication of this is that few people were admitted into the two programme and those who were not aware of them would continue to cause restiveness in the area. The programme has no focus and its implementation is baseless and very poor" and that the programme held nothing for the youths and women. The participants of the two programmes however differed on items 5.12, 5.13 and 5.19. While NDDC participants agreed that the programme was not well equipped for training, SPDC participants disagreed to this. Similarly SPDC trainees disagreed that the programme was more of roadside training and lack the capacity to train the youths while NDDC trainees agreed to the latter. NDDC trainees admitted that the training programme could not bring about rural community development while the SPDC participants affirmed that the programme was capable of bringing about rural/community development. (4) It Might also be that the programme has taken off.

Table 1: Graduates Perception site skills Acquisition program of SPDC and NDDC

\begin{tabular}{|l|l|l|l|l|}
\hline QUESTIONS & $\begin{array}{l}\text { MEAN } \\
\text { NDDC }\end{array}$ & REMARKS & $\begin{array}{l}\text { MEAN } \\
\text { SPDC }\end{array}$ & REMARKS \\
\hline
\end{tabular}




\begin{tabular}{|c|c|c|c|c|}
\hline $\begin{array}{l}\text { Youth Development Programme is } \\
\text { totally different and better than other } \\
\text { oil companies in my area. }\end{array}$ & 2.74 & Agreed & 2.51 & Agreed \\
\hline $\begin{array}{l}\text { The programme is political in nature, } \\
\text { only people loyal to and related to the } \\
\text { ruling party benefit more from the } \\
\text { programme. }\end{array}$ & 2.72 & Agreed & 2.44 & Disagreed \\
\hline $\begin{array}{l}\text { The programme has not yet taken off } \\
\text { in my community; we only hear of it } \\
\text { and read of it in the Newspaper/Radio. }\end{array}$ & 2.34 & Disagreed & 2.46 & Disagreed \\
\hline $\begin{array}{l}\text { The programme has no focus and its } \\
\text { implementation is baseless and very } \\
\text { poor. }\end{array}$ & 2.38 & Disagreed & 2.42 & Disagreed \\
\hline $\begin{array}{l}\text { The programme holds nothing for the } \\
\text { youths and women. }\end{array}$ & 2.22 & Disagreed & 2.41 & Disagreed \\
\hline $\begin{array}{l}\text { Only a pre-selected group/set are } \\
\text { favoured to benefit from the } \\
\text { scholarship/skills acquisition. }\end{array}$ & 2.67 & Agreed & 2.38 & Disagreed \\
\hline $\begin{array}{l}\text { The poor resource families are totally } \\
\text { marginalized. }\end{array}$ & 2.28 & Disagreed & 2.46 & Disagreed \\
\hline $\begin{array}{l}\text { No well-informed skills acquisition is } \\
\text { initiated by the programme } \\
\text { implementers but an ad-hoc type. }\end{array}$ & 2.31 & Disagreed & 2.28 & Disagreed \\
\hline $\begin{array}{l}\text { The programme is a ploy by the } \\
\text { government to deceive the oil } \\
\text { producing communities in order to } \\
\text { continue to exploit them. }\end{array}$ & 2.45 & Disagreed & 2.24 & Disagreed \\
\hline $\begin{array}{l}\text { The programme does assist her } \\
\text { graduates to secure job. }\end{array}$ & 2.75 & Agreed & 2.54 & Agreed \\
\hline $\begin{array}{l}\text { The programme candidates selection } \\
\text { creates problem }\end{array}$ & 2.38 & Disagreed & 2.46 & Disagreed \\
\hline $\begin{array}{l}\text { The programme is not well equipped } \\
\text { for training }\end{array}$ & 2.55 & Agreed & 2.36 & Disagreed \\
\hline $\begin{array}{l}\text { The programme is more of roadside } \\
\text { training and lack the capacity to train } \\
\text { the youths }\end{array}$ & 3.13 & Agreed & 1.77 & Disagreed \\
\hline $\begin{array}{l}\text { The programme does not have its own } \\
\text { building for training }\end{array}$ & 2.52 & Agreed & 2.07 & Agreed \\
\hline $\begin{array}{l}\text { Most facilities and learning materials } \\
\text { are out of date }\end{array}$ & 1.84 & Disagreed & 2.23 & Disagreed \\
\hline $\begin{array}{l}\text { This programme is not a means for } \\
\text { further education }\end{array}$ & 2.09 & Disagreed & 2.20 & Disagreed \\
\hline $\begin{array}{l}\text { The programme does not reduce } \\
\text { conflict and violence in your area }\end{array}$ & 2.19 & Disagreed & 2.16 & Disagreed \\
\hline $\begin{array}{l}\text { The programme cannot improve socio- } \\
\text { economic status of benefiting family }\end{array}$ & 2.48 & Disagreed & 2.15 & Disagreed \\
\hline $\begin{array}{l}\text { The training programme cannot bring } \\
\text { about rural community development }\end{array}$ & 3.76 & $\begin{array}{l}\text { Strongly } \\
\text { Agreed }\end{array}$ & 2.29 & Disagreed \\
\hline $\begin{array}{l}\text { The programme does not improve the } \\
\text { standard of living in the benefiting } \\
\text { family }\end{array}$ & 2.34 & Disagreed & 2.20 & Disagreed \\
\hline
\end{tabular}

Source: Field Data, 2009

Both groups however disagreed to the following items : "The poor resource families are totally marginalized"; "not well-informed skills acquisition was initiated by the programme implementers but an adhoc type"; and that the programme was a ploy by the government to deceive the oil producing communities in 
order to continue to exploit them". They both agreed that the programmes had no building of their own for training. None of the trainees in the two groups agreed that: the programme neither was a means for further education nor admitted that the most facilities and learning materials were out of date. They both disagreed that the programme did not reduce conflict and violence in their areas; the programme could not improve socioeconomic status of benefiting family nor able to improve the standard of living in benefiting family. The two programmes of SPDC and NDDC were yet to impact on the life of the rural youth. And until rural people secure job with the skills acquired and resettled to start on their own, violence and various criminalities would not be reduced.

It could generally be inferred from the result of this survey that most of the respondents were favourably disposed to the objectives and contents of the skills acquisition programme.

Table 2: Graduates Beneficiaries' Perception of the Skills Acquisition Programme of SPDC and NDDC

\begin{tabular}{|l|r|r|r|r|l|l|}
\hline $\begin{array}{l}\text { Anova: Single } \\
\text { Factor }\end{array}$ & & & & & & \\
\hline \multicolumn{1}{|c|}{ Groups } & Count & Sum & Average & Variance & & \\
\hline $\begin{array}{l}\text { Mean NDDC } \\
\text { score on } \\
\text { graduates } \\
\text { perception of } \\
\text { the programme }\end{array}$ & 20 & 49.7673 & 2.488365 & 0.167225 & & \\
\hline $\begin{array}{l}\text { Mean SPDC } \\
\text { score on } \\
\text { graduates' } \\
\text { perception of } \\
\text { the programme }\end{array}$ & 20 & 46 & 2.3 & 0.033469 & & \\
\hline & & & & & & \\
\hline ANOVA & & & & & & \\
\hline \multicolumn{1}{|l|}{$\begin{array}{l}\text { Source of } \\
\text { Variation }\end{array}$} & SS & $d f$ & MS & $F$ & P-value & F crit \\
\hline Between Groups & 0.354813 & 1 & 0.354813 & 3.53587 & 0.067736 & 4.098172 \\
\hline Within Groups & 3.813175 & 38 & 0.100347 & & & \\
\hline Total & 4.167988 & 39 & & & & \\
\hline
\end{tabular}

Source: Field Survey, 2009

\section{CONCLUSION AND RECOMMENDATION}

In conclusion, it is evidently seen from the result of this survey that most of the respondents were favorably disposed to the objectives and contents of the skills acquisition programme. Hence, it is strongly recommended that more married and unmarried youths be engaged and the sponsors of the two programmes should boost the perception of the graduates by ensuring that the graduates are promptly absorbed, employed or settled to do something to earn a living. Furthermore, there should be a joint evaluation/monitoring committee of (SPDC/NDDC) to ensure standard and quality so that the whole intention of running skills acquisition programme will be deferred.Given the recent proliferation of white-elephant projects and programmes in the nation and the continuous rise of programmes that are either inexpressive of the real and felt needs of the people or lack credibility due to corrupt practices; the two programmes (NDDC and SPDC) must demonstrate sincerity of purpose by supplying adequate training materials, learning equipment and also conduct follow up study on their programmes' graduates as ways of boosting the efficiency of the programmes in the future and develop effective mechanism for quality control and supervision for the programme.

\section{REFERENCES}

[1] Alagoa, E. J. (1999). Traditional Origin. In: The Land and People of Bayelsa State. E. J.Alagoa (Ed). Imo state: Onyoma Research Publication. pp 73-94.

[2] Anietie, U. (2006). NDDC Corporate Affairs Annual Reports. NDDC: Port Harcourt.

[3] Bakare, B. (2013) Addressing Youth Unemployment in Nigeria. BusinessDay (19 ${ }^{\text {th }}$ November, 2013). Pg. 14

[4] Eboh, C. (1999). Political Economy of National Development Issues and Perspectives.Owerri: Academic Publications and Development Resource Ltd. Pg. 78

[5] Gbagbo, H. M. O. \& Eze, B. I. (2014). Skills acquisition and entrepreneurship training for 
[6] youth, a panacea for unemployment and Nigerian insecurity. European Journal of Business and Management, 6 (25), 96 - 101.

[7] Nwachukwu, I. \& Ekanem, J. (2016). Oil exploration, environmental degradation and

[8] sustainable Agriculture in Niger Delta. Oshodi - Isolo, Nigeria: Mbeyi and associates Nigeria Ltd. Pg. 45

[9] Ogundele, O. J. K.; Akingbade, W. A., \& Akinlabi, H. B. (2012). Entrepreneurship training

[10] and education as strategic tools for poverty alleviation in Nigeria. American International Journal of Contemporary Research, 2(1), 148 - 155. 